\title{
Adsorption Mechanism of Direct Red Dye on Cellulose Acetate from Ananas comosus Leaves
}

\author{
ENDANG WIDJAJANTI LAKSONO*, MARFUATUN and SITI MARWATI \\ Faculty of Mathematics and Natural Sciences, Yogyakarta State University, Karangmalang, \\ Yogyakarta 55281, Indonesia. \\ *Corresponding author Email: endang_widjajanti@uny.ac.id \\ http://dx.doi.org/10.13005/ojc/330657
}

(Received: August 02, 2017; Accepted: September 05, 2017)

\begin{abstract}
The study describes the bacth experiment on technical diret red dyes removal from aqueos solution which use cellulose acetat prepared from Ananas comosus leaves. The Adsorption investigations were carried out in various of time, adsorbent mass, adsorbate concentration, and temperature. The adsorption kinetics followed a pseudo second order reaction. The equilibrium adsorption data was best presented by the Freundlich isotherm. The calculated thermodynamic parameters indicate that the ongoing adsorption process was endothermic and non-spontaneous in nature.
\end{abstract}

Keywords: Direct red dye, Cellulose acetate, Ananas comosus leaves, Kinetics,
Isotherm adsorption.

\section{INTRODUCTION}

Water pollution caused by untreated synthetic dye effluents released from textile industries has been concerned. The development of dye production relates the number of dye waste. The textile industry is the main contributor of dye waste into the environment. The characteristic of dye waste are base, hot, high of BOD and COD levels, and containing some dissolved solids. In the dyeing process the dye is partially absorbed by textile material, and the residue $(2-50 \%)$ goes to water ways ${ }^{1}$, or rarely be treated ${ }^{2}$ One of synthetic dye which use in Indonesia textile industries generally is direct red. Direct red is a di-azo compound containing several sulfonate groups. It has a soluble nature in water, low price, and easy to use.Unfortunately, it consumes long time to degrade, hence it potentially can be pollutant in water environment. Structure of direct red is shown in Figure. 1.

Many water pollutant treatment methods, such as coagulation, flocculation, photo catalytic degradation, membrane filtration, microbiological decomposition ${ }^{3}$, electrochemical oxidation, ${ }^{4}$ adsorption using fungi biosorbent ${ }^{5}$ have been applied. Adsorption is the process by which one substance (gas, liquid or solid) is taken into the body of another substance and the most popular method used to reduce dyes from waste water ${ }^{6}$, due to its economical and effectiveness removing a variety of pollutants including heavy metals, organic compounds and inorganic compounds ${ }^{7}$. Activated carbon has been reported as an ideal adsorbent to reduce the dye wastelevel in water. However, the 
activated carbon is less economical, due to the high production and regeneration costs 8 . But the use of activated carbon still requires advanced treatment for suspension, so as not to make new waste9 . Therefore, researchers began developing other cheaper adsorbents, such as bentonite, zeolite, and kaolin.

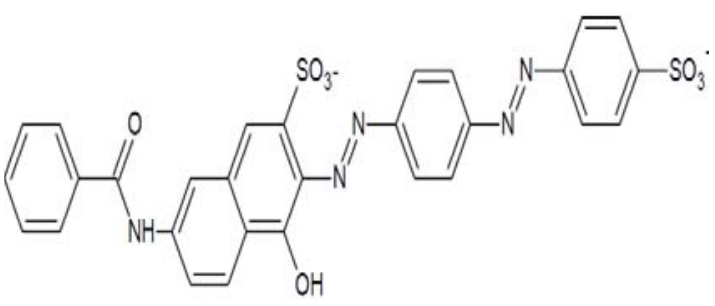

Fig.1. Direct red structure

Many materials have been used as adsorbents, such as diatomae ${ }^{10,11}$ and bentonite ${ }^{12}$. Biological adsorbents such as egg shell powder, ${ }^{13}$ peanut shell, ${ }^{14}$ jackfruit leaf powder ${ }^{15}$ and banana peels ${ }^{16}$ have been used to adsorb dyes. Unfortunately, these adsorbents show very low ability in adsorbing dyes. Development of cheaper, more efficient, and environmentally friendly adsorbent are of interest..

Polymer is one of best adsorbents. The polymer produces less sediment in adsorption process and widely used in batch or column separation method. Poly(N, N-dimethyl aminoethyl metacrylate) 17 , polypyrrole, ${ }^{18}$ and poly(vinyl alcohol) ${ }^{19}$ have been developed as adsorbents for dye waste. On the other hand, cellulose acetate, a derivative of cellulose,can also be used as an adsorbent. Cellulose acetate is a biodegradable polymer; the membrane has a sufficiently high mechanical strength and transparency. In addition, cellulose acetate is used as electrolyte membrane, photographic film, and specialty papers.

Exhaustive exploration on the adsorption kinetics involving wastewater treatment is important to providing better understanding of the reaction pathways and possible mechanisms involved ${ }^{20}$. We are reporting the use of cellulose acetate membrane obtained from leaves of pineapple (Ananas comosus) as an adsorbent to remove direct red in water. The equilibrium, kinetics and thermodynamics of dye adsoption by synthesized membranes are discussed

\section{MATERIALS AND METHODS}

\section{Materials}

Pineapple (Ananas comosus) leaves, an agriculturel waste, was obtained from pineapple farm in Yogyakarta. Toluene, ethanol, sulfuric acid, glacial acetic acid, sodium hydroxide, sodium hypochlorite, sodium chloride, $\mathrm{pH}$ buffer solution, technical direct red, and phenol-phtalien, and anhydride acetic acidwere purchased from Merck and were usedas received without any further purification.

\section{Adsorbent preparation}

Ananas comosus leaves were cut into small pieces and dried in the oven at $60^{\circ} \mathrm{C}$ and milled into powder. The cellulose was isolated by soaking the dry powder in a mixture of ethanol and toluene (1:2) for one hour. The cellulose was filter of and dried in $60^{\circ} \mathrm{C}$ for $3 \mathrm{~h}$. The dry cellulose was solvated in $2 \mathrm{M}$ sodium hydrochloride solution for $3 \mathrm{~h}$ to remove lignin, followed by bleaching process using sodium hypochloride solution. Finally, the cellulose was acetylated using glacial acetic acid, sulfuric acid and anhydride acetic acid. ${ }^{21,22}$

\section{Adsorbent characterization}

The adsorbent was characterized using FTIR method. The FTIR spectra of the cellulose acetate indicates functional groups of before and after adsorption. The Adsorption investigations were carried out in batch system in various oftime, concentration of adsorbate, and temperature of adsorption. The adsorption measurements were conducted by mixing $0.5 \mathrm{~g}$ of adsorbent in a 100 $\mathrm{cm}^{3}$ Erlenmeyer containing $50 \mathrm{~cm}^{3}$ of dye solution of known concentration. The solutions were agitated using an automatic shaker for a certain of time, and the supernatant solution was separated from the adsorbent by filtration using a Whatman No. 41 filter paper. The residual dye concentrations were analyzed using UV-Vis Spectrometer at 496 $\mathrm{nm}$ wavelength.

\section{RESULT AND DISCUSSION}

\section{Characterization of Adsorbent}

The extraction of Ananas comosus leaves yielded $20.71 \%$ cellulose. The acetylation process of cellulose produce $37.28 \%$ acetyl (degree of acetylation $\sim 2$ ) indicating that the compound was 
cellulose diacetate. The FTIR spectra of cellulose acetate before and after adsorption are depicted in Figure. 2.

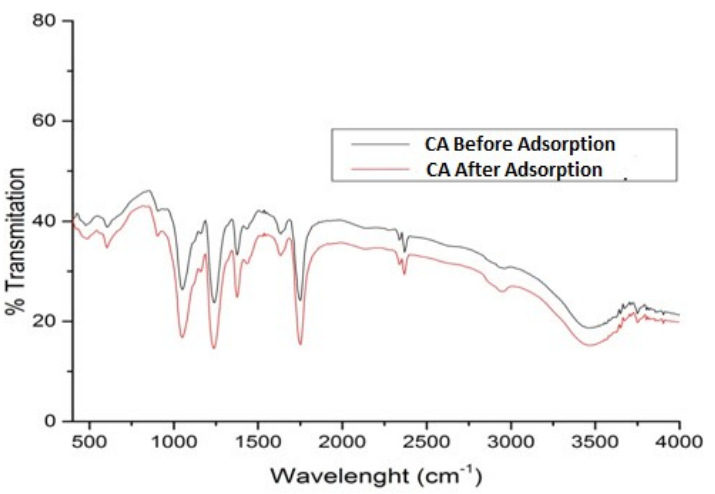

Fig. 2. FTIR Spectra of Cellulose Acetate

The absorption at $3749.62^{\mathrm{cm}-1}$, a broad peak at $3464.15^{\mathrm{cm}-1}$ and at $1373.32^{\mathrm{cm}-1}$ represent the free $\mathrm{OH}$ vibration, $\mathrm{OH}$ (bonded) stretching vibration, andof $\mathrm{OH}$ bending vibration, respectively. The peak at $1751.36^{\mathrm{cm}-1}$ represents the stretching vibration of $\mathrm{C}=\mathrm{O}$ in acetyl groups, whilepeak at $1049.28^{\mathrm{cm}-1}$ represents the $\mathrm{CO}$ stretching. The peak at $1242^{\mathrm{cm}-1}$ relates to the presence of $\mathrm{CH}$ deformation. FTIR spectra does not recognize the difference of the before and after adsorption samples due to the small amount of the adsorbate (ppm).

\section{Adsorption kinetics}

The constant rate of adsorption was determined from pseudo first order and pseudo second order equation. Determination of the reaction order was undertakenusing the optimum contact time of adsorption.

In order to study the constant rate of direct red, the pseudo first order equation, which wellknown Lagergren first order equation, was employed,. The value of In ( $q e-q t)$ was calculated at different temperature for interval time23,24:

$$
\ln \left(q_{e}-q_{t}\right)=\ln q_{e}-k_{1} t
$$

where $k 1\left(\mathrm{~min}^{-1}\right)$ is the pseudo first order adsorption kinetic parameter, qe and $q t$ denote the amount of direct red adsorbed at equilibrium and at any time $t$. The plot of pseudo first order is depicted in Figure 3. The In (qe-qt) value decreases along with time consumed in the adsorption process.

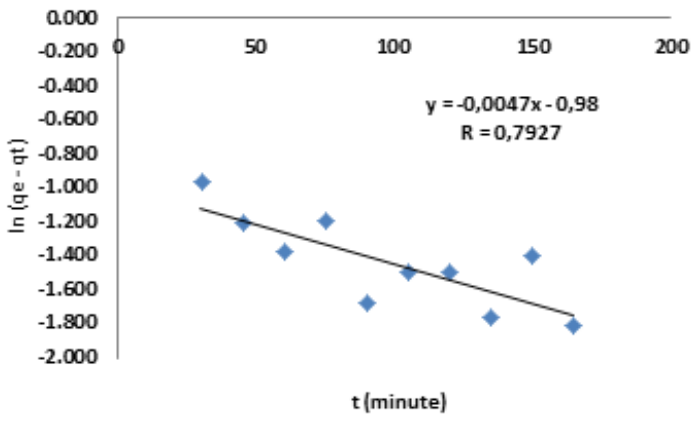

Fig.3. The plot of Pseudo first order

The pseudo second order equation in solution was represented by equation $2 .^{25}$

$$
\frac{t}{q t}=\frac{1}{k_{2} q_{e}^{2}}+\frac{t}{q_{e}}
$$

where $k_{2}\left(\mathrm{~min}^{-1}\right)$ is the second first order adsorption kinetic parameter. Fig. 4 shows the plot of second first order.

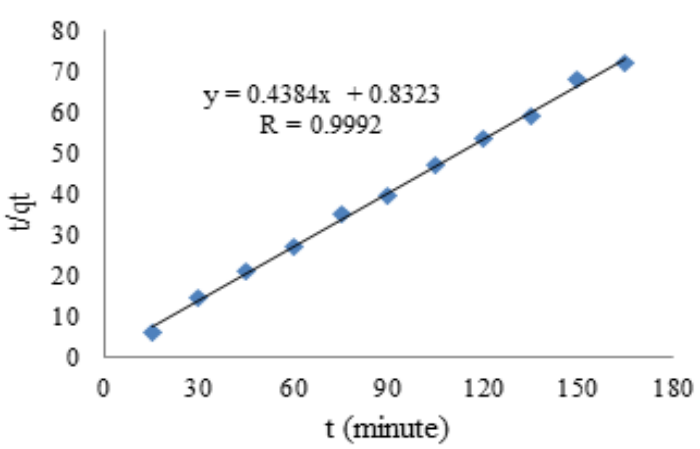

Fig.4. The plot of pseudo second order

By comparing Fig.1 and Fig.2, we conclude the best fit value of $k, q e_{\text {exp }}, q e,_{c a l}$ along with the correlation coefficient for all the adsorbateadsorbent system. The best values are given in Table 1 .

Table.1: Kinetics Parameter of Direct Red Adsorption by Cellulose Acetate

\begin{tabular}{lcc}
\hline Parameters & Pseudo first & Pseudo second \\
\hline$k$ & order & order \\
$k$ & 0.0047 & 0.1500 \\
$q e,{ }_{\text {exp }}(\mathrm{mg} / \mathrm{g})$ & 0.3753 & 2.2810 \\
$q e{ }_{\text {cal }}(\mathrm{mg} / \mathrm{g})$ & 2.4550 & 2.4550 \\
$\mathrm{R}$ & 0.7927 & 0.9992 \\
\hline
\end{tabular}

Table. 1 shows that $R$ value of Pseudo second order is greater than that of the Pseudo first order, indicating that the adsorption mechanism of 
direct red obeys the pseudo second order reaction. In this system, the adsorption process was controlled by chemisorptions which involved valence forces through sharing or exchange of electrons between the sorbent and the sorbate..$^{20,26}$ The adsorption process was conducted as a slow process (Figure. 4).

\section{Adsorption isotherm}

Determination of adsorption isotherms was undertaken using data of adsorption capacity at various initial concentration of direct red solution. The experimental equilibrium adsorption data have been tested using Langmuir and Freundlich isotherm equations. The applicability of these isotherms equation to describe the adsorption process was adjudged by the correlation coefficient or $R$ values. ${ }^{21,27}$

Langmuir isotherm is determined by plottingthe equilibrium liquid phase concentration $(\mathrm{Ce})$ vs. Ce/qe, where qe is the equilibrium adsorption capacity. The Langmuir isotherm is

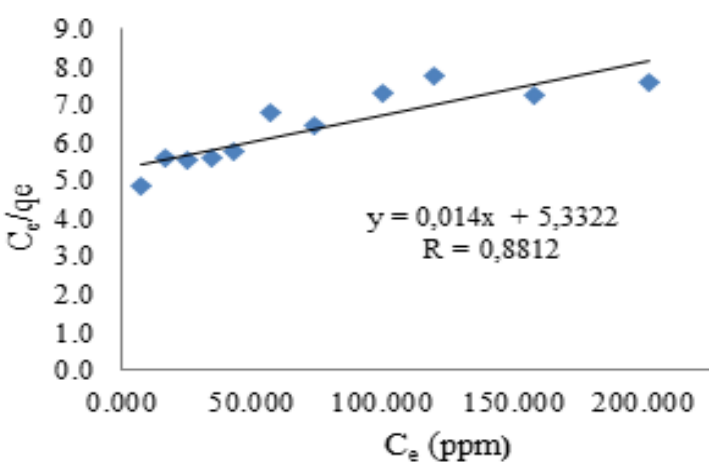

Fig.5. Langmuir Isotherm

shown in Figure.5.

The plot of $C e v s$ qe. log qegives a straight line with slope $1 / n$ and intercept of $\log K F$, where $K F$ is the Langmuir constant. The Freundlich isotherm was described in Figure.6. The parameters of the isotherm and $R$ values are listed in Table 2 .

Table.2 indicates that $R$ value of Freundlich isotherm is greater than 0.949 , i.e. the Freundlich giving the best fit. Freundlich isotherm is based on the assumption that adsorption occurs on a heterogeneous adsorption surface having

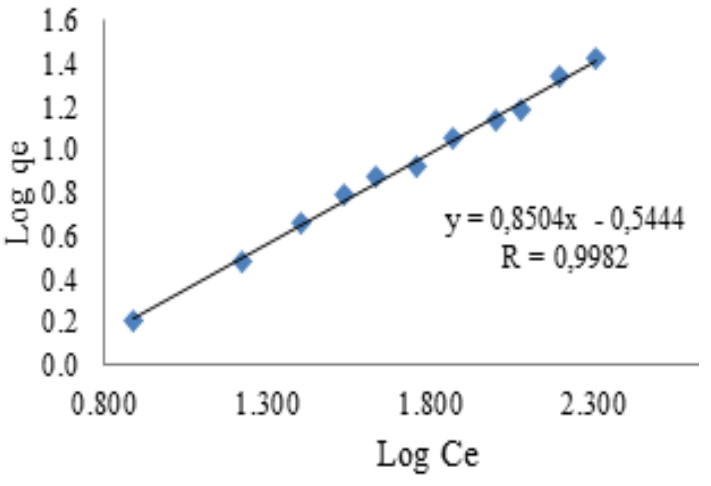

Fig.6. Freundlich Isotherm

unequally available sites with different energy of adsorption. ${ }^{28}$ According with Ayawei et $a^{29}$ and Vimonses ${ }^{30}$, the Freundlich isotherm constant can be used to explore the favourability of adsorption process. The adsorption process is favourable if the value of $n$ satisfies the condition $|1|<n<|10|$. We found that the value of $n=1,1759(1 / n=0,8504)$ indicating that the adsorption of direct red into cellulose acetate is favourable.

Table. 2: The parameters of isotherm

\begin{tabular}{lcc}
\hline Parameters & Langmuir & Freundlich \\
\hline Constant (K) & 0,003 & 0,2855 \\
Qo & $71,429 \mathrm{mg} / \mathrm{g}$ & - \\
$1 / \mathrm{n}$ & - & 0,8504 \\
$\mathrm{R}$ & 0,8812 & 0.9982 \\
\hline
\end{tabular}

The thermodynamic parameters were determined by measuring the effect of temperature on adsorption capacity. We observed that the increase of temperature is accompanied by the increase of adsorption capacity. This implies that the adsorption is endothermic process.

The measurable thermodynamic parameters include the change in free energy $\left(\Delta G^{\circ}\right)$, enthalpy $\left(\Delta \mathrm{H}^{\circ}\right)$, and entropy $\left(\Delta \mathrm{S}^{\circ}\right)$, which may be determined using the following equation ${ }^{23,31}$ :

$$
\Delta G^{\circ}=\Delta H^{\circ}-T \Delta S^{\circ}
$$

The values of $\Delta \mathrm{H}^{\circ}$ and $\Delta \mathrm{S}^{\circ}$ were calculated by plotting $1 / T$ vs $\ln K_{d}$, where $K_{d}$ is the distribution coefficient. $K_{d}$ chase concentration after time $t$ $\left(C_{t}\right)$.The plot can be seen in Figure. 7. 


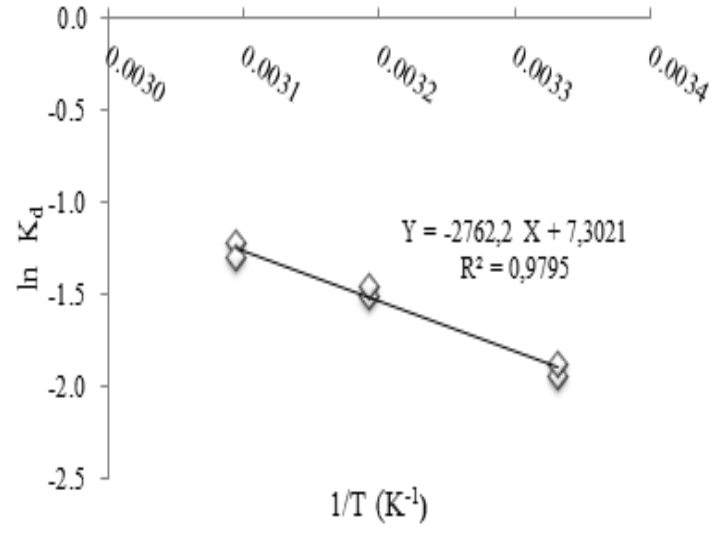

Fig.7. Thermodynamic plot for adsorption

Based on Fig.7, the values of $\Delta \mathrm{H}^{\circ}$ and $\Delta \mathrm{S}^{\circ}$

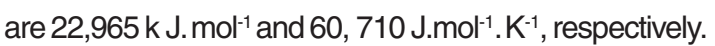
The values of $\Delta G^{\circ}$ in each temperature is listed in Table 3.

Endothermic nature is indicated by the positive value of $\Delta \mathrm{H}^{\circ}$, the increase of $\Delta$ So and the decrease of $\Delta \mathrm{G}^{\circ} .32$ The positive value of $\Delta \mathrm{G}^{\circ}$ indicates that absorption is nonspontaneous. The positive value of $\Delta S^{\circ}$ indicates the increasein randomness.
Table. 3: The values of Gibbsfree energy

\begin{tabular}{lrrr}
\hline Temperature (K) & 300.15 & 313.15 & 323.15 \\
\hline$\Delta$ Go (kJ.mol-1) & 4.743 & 3.954 & 3.347 \\
\hline \multicolumn{4}{c}{ CONCLUSION }
\end{tabular}

The cellulose acetate prepared using Ananas comosus leaves is effective for removing the reactive direct red in aqueos solutions. Adsorption kinetics follow pseudo second order reaction. Equilibrium adsorption data presents the Freundlich isotherm. The calculated thermodynamic parameters indicate that the ongoing adsorption process is endothermic and nonspontaneous.

\section{ACKNOLEDGEMENT}

This work was supported financially by DIPA Yogyakarta State University,and the authors would like to thank Desiyuning for her help in preresearch.

\section{REFERENCES}

1. Joviæ, M.; Stancoviæ D.; Manojloviæ, D.; Anðelkoviæ, I.; Miliæ, A.; Dojèinoviæ, B.; danRogliæ G. Study of The Electrochemical Oxidation of Reactive Textile Dyes Using Platinum Electrode. International Journal of Electrochemical Science, 2013, 8, 168-183

2. Ratna, P. Pollution due to synthetic dyes toxicity \& carcinogenicity studies and remediation. International Journal of Environmental Sciences. 2012, 3(3): 940-955.

3. Pearce, C. ; Lyloyd, J. ; \& Guthrie, J. The Removal of Colour from Textile Wastewater using whole Bacterial Cell a Review. Dyes Pigm , 2003, 58(3) :179- 196.

4. Vlyssides, A.; Loizidou, M.; \& Karlis, P. (1999). Electrochemical Oxidation of a Textiledye wastewater using a Pt/Ti electrode, $\mathrm{J}$ Hazard Mater.1999, 23, 70(1-2):41-52.

5. Fu, Y., \& Viraraghavan, T. Removal of Congo Red from an Aqueous Solution by Fungus Aspergillus Niger. Adv. Environ Res, 2002. 7(1):239-247.

6. Wong, Y.C.; Ranjini, K.N.; Wan-Nurdiyana,
W.A. Removal of congo red and acid yellow 36 dye using orange peel and rice husk as absorbents. Oriental Journal of Chemistry. 2014, 30(2), 529-539.

7. Chakraborty, S. ; De, S. ; Das, G. S., \& Basu, J. Adsorption study for the removal of a basic dye: experimental and modeling. Chemosphere. 2005, 58 (8):1079-1086.

8. Baseri, J. ; Palanisamy, P. ; \& Sivakumar, P. Application of Polyaniline Nano Composite for Adsorption of Acid Dye from Aqueous Solution. E-journal of Chemistry, 2012 , 9(3) 1266- 1275.

9. Mohammed, M.; Shitu, A.; Ibrahim, A. Removal of methylene blue using low cost adsorbent: A review. Research Journal of Chemical Sciences. 2014, 4(1), 91-102.

10. BadiiKhashayar, Faramarz DA, Saberi, Masoud A; Limaee, Narges Y; Shafaei, Seyed Zia-e- din, Adsorption of Acid Blue Dye on Diatomite in aqueous Solutions, Indian Journal of Chem. Technol, 2010, 17(1): 7-16

11. Shawabkeh RA, \&Tutuji MF, 2003, 
Experimental Study and Modeling of Basic Dye Sorption by Diatomaceous Clay. Appl Clay.Sci, 2003, 24(1-2), 111-120

12. Sonawane S. ; Chaudhari,P. ; Ghodkhe, S. Phadtare. S; Meshram. S; Ultrasound assisted adsorption of basic dye onto organically modified bentonite (nanoclay), J. Sci. Ind RES, 2009. 68(2), 162-167

13. Rajashree Kobiraj. ; Neha Gupta, Atul Kumar Kuwashaa and M.C Chattopadhyaya, Determination of equilibrium, kinetic and thermodynamic parameters for the adsorption of Briliant green dye from aqueous solutions onto eggshell powder, Indian Journal of Chemical Technology, 2012, 19 (1):26-31

14. Gong R.Ding. ; Li M. Yang C. ; Liu H \& Sun Y. Utilization of Powdered Peanut Hull as Biosorben for Removal of Anionics dyes from aqueous Solution, Dyes. Pigm, 2005, 64(3): 187-192

15. Tamez Md. Uddin.; Md. Rukanuzzaman.; Md.Maksudur Rahaman Khan and Md. Akhtarul Islam. Jackfruit (arthocarpu sheterophyllus) leaf Powder. An effective adsorbent for removal of methylene blue from aqueous solutions.Indian Journal of Chem. Technol, 2009, 16(2), 142-149.

16. Endang Widjajanti LFX.; Marfuatun, Dewi Yuanita. Adsorption behaviour of azo dyes by banana peel biosorbents, J Sains Dasar, 2013, 2(2):8-16

17. Solpan, D. ; Sen, M. ; Kolge, Z. ; Torun, M. ; \& Guveri, O. ; Adsorption of Some Dyes on Cationic Poly(N,N-Dimethyl Amino Ethylmethacrylate) Hydrogel., Heccetepe J. Bio \& Chem , 2009, 37(3): 233-240

18. Ansari, R. ; \& Mosayebzadeh, Z. Removal of Eosin Y, an Anionic Dye, from Aqueous Solutions Using Conducting Electroactive Polymers., Iranian Polymer Journal , 2010, 19 (7) :541-551.

19. Gehlot, P. ; Daga, K. ; \& Mehta, R. Adsoprtion Study of Dye Water Using Poly Vynil Alcohol Coated Carbon Black as an Effective and Low Cost Adsorbent., Inter. Journal of Chemistry, 2011, 3 (3):56-61.

20. Sumalapao D.E.P. ; Distor, J. RDitan. ; I.D, Domingo, N.T.S. ; DY, L.F. ; Villarante, N.R, Biosorption Kinetic Models on the Removal of Congo redonto Unripe Calamansi (Citrus microcarpa) peels, Orient. J. Chem., 2016, 32(6): 2889-2900

21. Daniel Alves Cerqueira. ; Guimes Rodrigues Filho. ; Carla da Silva Meireles. Optimization of Sugarcane Bagasse Cellulose Acetylation. Carbohydrate Polymers, 2007, 69(3) : 578-582

22. JieCai.; PengFei.; Zhouyi Xiong.; Yongjun Shi.;
Kai Yan \&Hanguo Xiong. Surface Acetylation of Bamboo Cellulose : Preparation and Rheological Properties. Carbohydrate Polymers, 2013.92(1) : 11-18

23. Abechi, E.S.; Gimba, C.E.; Azairu, A.; andKagbu, J.A. Kinetics of Adsorption of Methylene Blue onto Activated Carbon Prepared from Palm Kernel Shell. Archieved of Applied Science Research,2011, 3(1): 154-164

24. Nandi B.; Goswami A.; Purkait M. Removal of cationic dyes from aqueous solutions by kaolin: kinetic and equilibrium studies. Appl Clay Sci, 2009. 42(3-4):583-90.

25. Ho. Y.S. ; Mckay. G. ; Pseudo-second order model for sorption process.Process Biochem. 1999. 34(5): 451-465.

26. Okewale A.O.; Babayemi, K.A.; Olalekan A.P. Adsorption Isotherms and Kinetics Models of Starchy Adsorbents on Uptake of Water from Ethanol - Water Systems. International Journal of Applied Science and Technology, 2013. 3 (1), 35-42

27. Zawani, Z.; Luqman, C.A.; Thomas, S.Y.C. Equilibrium, Kinetics and Thermodynamic Studies: Adsorpstion of Remazol Black 5 on the Palm Kernel Shell Activated Carbon (PKS- AC). Eur. J. Sci. Res, 2009. 37(1) : 63-71

28. Ramachandran, P.; Vairamuthu, R.; Ponnusamy, S. Adsorption Isotherms, Kinetics, Thermodynamics and Desorption Studies of Reactive Orange 16 on Activated Carbon Derived from Ananascomosus $(L)$. Carbon.2016. ARPN 6 (11): 15-26

29. Ayawei, N.; Ekubo, A.T.; Wankasi, D.; Dikio, E.D. Adsorption of congo red by $\mathrm{Ni} / \mathrm{Al}-\mathrm{CO} 3$ : Equilibrium, Thermodynamic, and Kinetic Studies. Oriental Journal of Chemistry.2015, 31(3): 1307-1308.

30. Vimonses, V.; Lei, S.; Jin, B.; Chow, C.W.K. and Saint, C. Kinetic Study and Equilibrium Isotherm Analysis of Congo Red Adsorption by Clay Materials. Chemical Engineering Journal, 2009.148(2-3): 354-364.

31. Yusra, S and Bhatti, H.N. Kinetic and Thermodynamic Modeling for the Removal of Direct Red-31 and Direct Orange-26 Dyes from Aqueus Solution by Rice Husk.Desalination, 2011.272(1-3): 313-322

32. Yaneva, Z.L. and Georgieva, N.V. Insights into Congo Red Adsorption on Agro Industrial Materials-Spectral, Equilibrium, Kinetic, Thermodynamic, Dynamic and Desorption Studies. A Review.International Review of ChemicalEngineering, 2012.4(2): 127-146. 